\& Research Square

\title{
Association Between the Dietary Literacy of Children's Daily Diet Providers and School-age Children's Nutritional Status and Eating Behaviours: A Cross- sectional Study
}

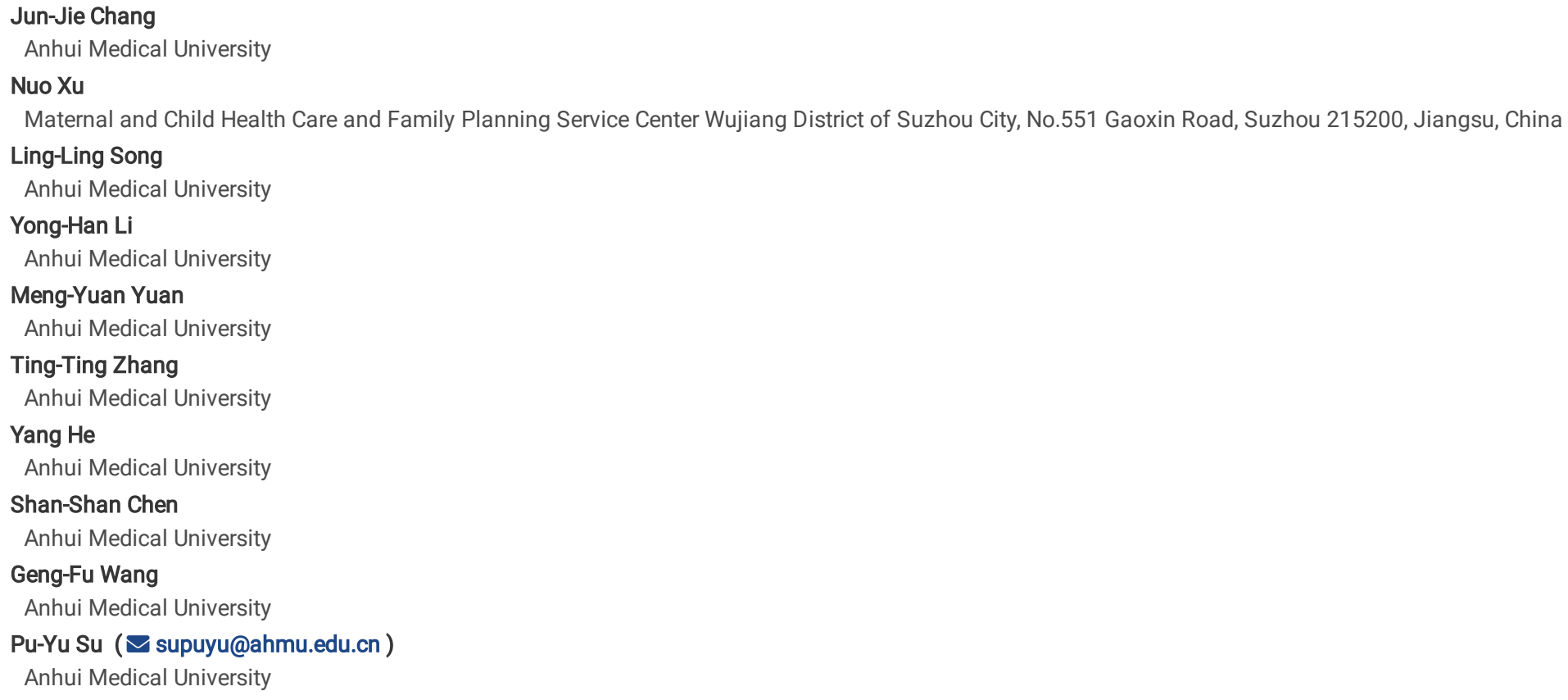

\section{Research Article}

Keywords: Eating behavior, Nutritional status, School-age children, Dietary literacy

Posted Date: November 17th, 2021

DOI: https://doi.org/10.21203/rs.3.rs-1050128/v1

License: (1) (7) This work is licensed under a Creative Commons Attribution 4.0 International License. Read Full License 


\section{Abstract}

Background

Overweight and obesity rates have increased rapidly in Chinese school-age children, and previous studies have indicated that poor dietary literacy can lead to poor eating behaviours. However, few studies have investigated the association between the dietary literacy of daily diet providers and the eating behaviours and nutritional status of school-age children raised by the providers. Thus, we aimed to explore this association.

Methods

We collected data on the eating behaviours and nutritional status of children in two primary schools in Anhui Province, as well as the dietary literacy of their daily diet providers. T-tests, one-way ANOVA, and multiple linear regression were used to analyse the association.

Results

We found significant differences in the scores on the Questionnaire of Children's Daily Diet Providers' Dietary Literacy (QCDDPDL) by region, relationship with the child, age, and educational level of the daily diet provider (all $p<.05$ ). Moreover, the children in the low QCDDPDL score group were inclined to engage in unhealthy eating behaviours $(p<.05)$. In addition, the incidence of overweight and obesity was higher in the low QCDDPDL attitude score group than the high score group $(p=.006)$.

Conclusions

Our study showed that the dietary literacy of diet providers may influence children's health and eating behaviours. Improving the dietary literacy of diet providers may promote the health status and eating behaviours of school-age children.

\section{Introduction}

The problem of overweight and obesity in children has become increasingly serious, affecting their current and even life-long health. A large sample taken in 2014 showed that the prevalence of overweight and obesity was $19.3 \%$ in Chinese students aged 7 to 18 , which had increased significantly compared to decades ago [1]. Obesity increases the risk of physical and psychological problems, including type 2 diabetes, cardiovascular and liver disease as well as social discrimination, low self-esteem, and depression [2]. Obesity and malnutrition in children are mainly caused by poor eating behaviours, which means that obesity is related to dietary factors [3]; the American Dietetic Advisory Committee recommended that overweight and obese individuals lose weight by eating healthily [4].

The problem of obesity and malnutrition can be improved by strengthening dietary literacy, which is one of the important factors affecting public health [5]. In light of the age of children and their long-term relationships with diet providers, eating behaviours of children, such as food selection, are mainly affected by the dietary literacy of their diet providers. Providers with high dietary literacy are good at using nutritional information to make healthy decisions [6]. The knowledge, attitudes, and behaviours of diet providers affect their food choices and in turn affect their children's eating behaviours and health status. On the other hand, providers with low dietary literacy probably do not choose beneficial foods for their children by reading food labels and nutrient contents. In addition, providers' encouragement, occupational status, and educational level were found to be correlated with children's consumption of healthy food [7] Therefore, the dietary literacy of children's daily diet providers affects not only their health but also children's health and eating behaviours [8].

Based on the above theories, this study investigated the nutritional status and eating behaviours of 1,137 children in grades 3 to 6 from two primary schools in urban and rural areas of Hefei, Anhui Province. The dietary literacy of children's daily diet providers was investigated to analyse the association between the dietary literacy of daily diet providers and children's nutritional status and eating behaviours.

\section{Methods}

\section{Participants}

One primary school from an urban area and another from a rural area were selected by stratified cluster sampling in Hefei, Anhui Province, which is in central China, in November 2018. All students in grades 3 to 6 were included in the investigation after informed consent was obtained from the children's daily diet providers and assent was provided by the students. A total of 1,137 children and their daily diet providers participated in this study. Those who did not complete the questionnaire and those who did not provide peripheral blood samples were excluded. Ultimately, 1,043 children were included, for an effective rate of $91.7 \%$. Among these children, 693 (66.4\%) were from the urban area and 350 (33.6\%) were from the rural area; boys and girls accounted for almost half each, and their ages ranged from 7 to 13 years, with a mean of $9.89 \pm 1.32$ years. Ethics approval was given by the Biomedicine Ethics Committee of Anhui Medical University (No. 20170386).

\section{Questionnaire}

A self-report questionnaire was used to conduct a cross-sectional survey of children's daily diet providers; the questionnaire mainly included questions on the general demographic characteristics, such as the child's birthplace (urban, rural), sex (male, female), age, only child status of the child (yes, no) and the education level of the child's daily diet provider. Additionally, the dietary literacy of providers was evaluated by the Questionnaire of Children's Daily Diet Providers' Dietary Literacy (QCDDPDL), which was developed by our research group [9]. The questionnaire consists of 30 items that investigate the dietary literacy of daily diet providers from four dimensions, namely, attitude (7 items), actions (7 items), skills (9 items), and environment (7 items), by using a 4-point

Page 2/11 
Likert scale $(0=$ very inconsistent, $3=$ very consistent). The score of each dimension and the total score were calculated. A higher score indicates a stronger ability of the child's daily diet provider to use dietary nutrition knowledge to improve the child's health status (Additional file 1: Supplement Table 1). In this study, the Cronbach's a coefficient, split-half reliability, and test-retest reliability of the QCDDPDL were $0.874,0.813$, and 0.878 , respectively. To better compare the effects of dietary literacy of diet providers on children's eating behaviours and nutritional status, the score of each dimension and total score were divided into the low group $\left(<P_{25}\right)$, moderate group $\left(P_{25}\right.$ to $\left.P_{75}\right)$, and high group $\left(>P_{75}\right)$ [10]. The Children's Eating Behaviour Questionnaire (CEBQ), which was developed by the British scholar Wardle and colleagues in 2001, was used to assess children's eating behaviours [11]. The CEBQ contains 35 items that evaluate children's eating behaviours from 8 dimensions (satiety responsiveness, slowness in eating, food fussiness, food responsiveness, enjoyment of food, desire to drink, emotional undereating, and emotional overeating). The CEBQ entries are scored on a 5-point Likert scale ( $1=$ never, $5=$ always), and the score of each dimension is calculated separately. A higher score indicates stronger characteristics of this dimension. In this study, 64 school-age children were retested 1 week after the survey, and the retest reliability of the questionnaire score ranged from 0.86 to 0.93 for each dimension.

\section{Detection of children's nutritional status}

\section{BMI and body fat percentage}

The weight and height of children were measured to calculate BMI, using the formula BMI = weight $(\mathrm{kg}) / \mathrm{height}^{2}\left(\mathrm{~m}^{2}\right)$. The research subjects were divided into 3 categories (wasting, normal, and overweight or obese) according to the BMI standards for the nutritional status of children aged 7-18 in China [12]. For a detailed division, see Additional file 2: Supplement Table 2. For the children, skinfold thickness of the upper triceps and subscapular folds were measured by sebaceous callipers. The measured skinfold thickness was converted into body fat density using the Japanese Changling formula, and then the percentage of body fat was estimated using the modified formula of Brozek [13]. The body fat percentage was divided by quartile. $P_{25}$ to $P_{75}$ was considered the normal control group, $<P_{25}$ was considered the low body fat group, and $>P_{75}$ was considered the high body fat group [14].

\section{Haemoglobin}

A haemoglobin strip (dry chemical method) was used to test the haemoglobin content in the blood from the fingertips of children. $\mathrm{Hb}<115 \mathrm{~g} / \mathrm{L}$ in children aged 5 to 11 and $\mathrm{Hb}<120 \mathrm{~g} / \mathrm{L}$ in children aged 12 to 14 were used as the defining criteria for nutritional anaemia in children based on the WHO recommended standards [15].

\section{Trace elements}

Forty microlitres of blood from the fingertips of children was aspirated by using a micropipette and measured within $2 \mathrm{~h}$ after shaking. The contents of $\mathrm{Zn}$, Ca, and Fe elements in the sample were detected by the standard curve method using a BH5500 atomic absorption spectrometer (Beijing Bohui Innovative Photoelectric Technology Co., Ltd., Beijing). The children's trace element contents were divided into normal and deficient groups by the detection criteria. Reference ranges of normal values of $\mathrm{Ca}, \mathrm{Fe}$, and $\mathrm{Zn}$ in children aged 6 to 11 years were 1.51 to $2.01 \mathrm{mmol} / \mathrm{L}, 7.36$ to $9.34 \mathrm{mmol} / \mathrm{L}$, and 67.72 to 103.84 $\mu \mathrm{mol} / \mathrm{L}$, respectively; reference ranges of normal values of $\mathrm{Ca}$, Fe, and $\mathrm{Zn}$ in children aged 12 to 14 years were 1.42 to $1.90 \mathrm{mmol} / \mathrm{L}, 7.16$ to $9.85 \mathrm{mmol} / \mathrm{L}$, and 71.46 to $111.33 \mu \mathrm{mol} / \mathrm{L}$, respectively.

\section{Quality control}

The children took the questionnaire home after school (an instruction manual was attached to guide the diet provider); the questionnaire was completed by their guardians who mainly provided meals for them and were returned the next morning. The headteacher was in charge of this process. The measurement of physical development was completed by child healthcare workers. All instruments for laboratory testing were calibrated, and the testing was completed by laboratory professionals.

\section{Statistical analysis}

The database was established by entering the contents of the questionnaire into EpiData 3.1, and SPSS 21.0 was used for statistical analysis. We performed Student's $t$-test and one-way ANOVA to compare the dietary literacy scores of daily diet providers based on different demographic characteristics. Meanwhile, the relationships between different dietary literacy groups of daily diet providers and the nutritional status of school-age children were examined by chi-square test. Multiple linear regression analysis (controlling for confounding factors) was used to explore the association between daily diet providers' dietary literacy and school-age children's eating behaviours. $p<.05$ was considered significant.

\section{Results}

In total, 1,043 participants completed our research, for a response rate of 91.7\%. Table 1 shows that there were significant differences in the school-age children's daily diet providers' dietary literacy dimensions and total scores by region, relationship with the child, age, and educational level of the daily diet provider. The scores of all dimensions were higher for diet providers from urban areas than those from rural areas, and the dietary literacy scores were generally higher for younger parents, had a higher educational level and had a better self-assessed economic status.

Table 2 shows that there was no significant difference in the distribution of the percentage of body fat or haemoglobin content among the different dietary literacy groups. However, there was a significant difference in the distribution of BMI among children of daily diet providers with different dietary literacy attitudes $(p=.006)$. For comparison of trace elements among different dietary literacy groups, Table 3 shows that the contents of calcium, iron, and zinc did not differ significantly among children in the low, moderate, and high dietary literacy groups for each dimension and the total score. Table 4 shows that 
children raised by diet providers with high total dietary literacy compared with those raised by diet providers with low total dietary literacy had lower scores in various eating behaviours except for slowness in eating.

Multiple linear regression analysis was performed using the score of each dimension of school-age children's eating behaviours as the dependent variable, the score of each dimension of daily diet providers' dietary literacy of school-age children as the independent variable, and area of residence, gender, age, only child status, and education as covariates. Table 5 shows that the high total score group of providers' dietary literacy was associated with the reduced occurrence of poor eating behaviours (satiety responsiveness, slowness in eating, food fussiness, food responsiveness, desire to drink, emotional undereating, and emotional overeating) $(\beta<0, p<.05)$ and the formation of healthy eating behaviours (enjoyment of food) of children $(\beta>0, p<.05)$, while the differences in the influence of the moderate score group on children's eating behaviours compared with the low score group were not particularly obvious.

\section{Discussion}

The results of this survey showed that diet providers' dietary literacy was indeed related to the eating behaviour of their children. However, no correlation was found between the nutritional status of the child (body fat percentage, haemoglobin, calcium, iron, zinc) and the dietary literacy of their diet providers in these two primary schools. Meanwhile, we found that providers who lived in cities with ages ranging from 30 to 40 had better dietary literacy, which was consistent with previous research [16]. For urban children who live in better educated families, their daily diet providers pay more attention to dietary nutrition and purchase more suitable food for children's growth and development [17]. Compared to other providers, well-educated providers are able to make more informed decisions in caring for their children, so as the main daily diet providers, they will help their children develop healthy eating behaviours.

In our study, the association between the daily dietary literacy score of providers and children's BMI was statistically significant only in the attitude dimension. A reasonable explanation was that the high dietary literacy score of providers who find their children overweight would take measures to prevent their children from being overweight and obese [18]. However, we did not find an association between the contents of trace elements in the children's peripheral blood and the providers' dietary literacy. On the one hand, with the development of the economy, dietary providers have access to abundant food; thus, children's intake of nutrients is sufficient. In addition to sources of various trace elements from the daily diet, children can also obtain calcium, iron, and other nutrients through supplements [19]. Therefore, this may obscure the effect of the dietary literacy of providers on children's trace element status [20].

The scores of the dietary literacy attitude, behaviour, skill, and environment dimensions and the total dietary literacy score of school-age children's daily diet providers were significantly correlated with most eating behaviours of the children. The multiple linear regression results suggested that the total score of daily dietary literacy of diet providers was negatively associated with children's satiety responsiveness, slowness in eating, food fussiness, food responsiveness, desire to drink, emotional undereating, and emotional overeating behaviours but positively associated with children's enjoyment of food. Previous studies showed that obese children were more sensitive to the smell of food and more likely to overeat after exposure to preferred foods than normal-weight children. Overreaction to food may not be limited to food choices but also include beverages, especially sugar-sweetened beverages, which are associated with weight gain $[21,22]$. A study on dietary patterns and nutritional status of Kenyan Nairobi children found that the higher the providers' dietary literacy score, the more fruit, vegetables, and milk their children consumed daily [23]. Another study found that parents' dietary habits and feeding strategies were the most important determinants of children's eating behaviours and food choices [24]. Generally, unhealthy eating behaviours can increase the risk of obesity and even some diseases, such as diabetes, hyperlipidaemia, and cardiovascular disease [25]. As an important factor affecting children's eating behaviours [26], it is necessary to improve the dietary literacy of diet providers of children. For children's development, parents should provide children with sufficient and healthy food to choose from. At the same time, parents should strengthen their dietary literacy and transmit their healthy eating behaviours and dietary concepts to future generations.

\section{Limitations}

There were some deficiencies in this study. First, more than one person may provide children with their daily diets, such as when both parents participate; however, this study only investigated the dietary literacy of one provider, and the results may not be sufficiently accurate. In addition, due to dietary culture, religious beliefs, and other factors, there are large differences in food choices in different regions. This study only conducted a sample survey in one region, and the survey results cannot be generalized. It is necessary to survey a larger sample population in future studies.

\section{Conclusions}

In this study, the dietary literacy of school-age children's daily diet providers affected children's eating behaviours. Although no association was found between the nutritional status of children and the dietary literacy of their dietary providers, previous studies have shown that unhealthy eating behaviours increase the risk of some chronic diseases. Therefore, we can improve the dietary literacy of children's diet providers to cultivate children's healthy eating behaviours. Additionally, appropriate intervention measures should be formulated with full consideration of socioeconomic and educational levels to reduce the risk of children's nutrition-related diseases and promote children's physical and mental health. In addition, based on the proposed interventions, community trials can be carried out to evaluate the effects of the interventions.

\section{Abbreviations}

QCDDPD: The Questionnaire of Children's Daily Diet Providers' Dietary Literacy; CEBQ: The Children's Eating Behaviour Questionnaire; BMI: Body mass index; ANOVA: Analysis of Variance. 


\section{Declarations}

\section{Acknowledgments}

We are extremely grateful to all of the participants and thank American Journal Experts for professional language editing (the verification code FB89-F934656C-7F27-415P).

\section{Authors' Contributions}

GFW and PYS supervised this work. YH and SSC collected the data. YHL, TTZ, MYY, and LLS analyzed the data. JJC and NX wrote the manuscript. All authors read and approved the final manuscript.

\section{Funding}

This research was funded by the Dietary Nutrition Research and Education Fund of Danone Nutrition Center, grant number (DIC2017-02).

\section{Availability of data and materials}

The data presented in this study are available upon request to the corresponding author.

\section{Ethics approval and consent to participate}

This study was approved by The Biomedicine Ethical Committee of Anhui Medical University (No.20170386). All methods were performed in accordance with the relevant guidelines and regulations. Informed consent was obtained from the caregives of the participants involved in the study.

\section{Consent for publication}

Not applicable.

\section{Competing interests}

The authors declare that there is no conflict of interest.

\section{Author details}

${ }^{1}$ Department of Maternal, Child and Adolescent Health, School of Public Health, Anhui Medical University, No.81 Meishan Road, Hefei 230032 , Anhui, China.

${ }^{2}$ Maternal and Child Health Care and Family Planning Service Center Wujiang District of Suzhou City, No.551 Gaoxin Road, Suzhou 215200, Jiangsu, China.

\section{References}

1. Wang S, Dong YH, Wang ZH, Zou ZY, Ma J. Trends in overweight and obesity among Chinese children of 7-18 years old during 1985-2014. Chin J Pre Med. 2017; 51(4):300-05. https://doi.org/10.3760/cma.j.issn.0253-9624.2017.04.005

2. Vaitkeviciute R, Ball LE, Harris N. The relationship between food literacy and dietary intake in adolescents: A systematic review. Public Health Nutr. 2015; 18(4):649-58. https://doi.org/10.1017/s1368980014000962

3. Njardvik U, Klar EK, Thorsdottir F. The factor structure of the Children's Eating Behaviour Questionnaire: A comparison of four models using confirmatory factor analysis. Health Sci Rep. 2018; 1(3):e28. https://doi.org/10.1002/hsr2.28

4. Smethers AD, Rolls BJ. Dietary management of obesity: Cornerstones of healthy eating patterns. Med Clin North Am. 2018; 102(1):10724. https://doi.org/10.1016/j.mcna.2017.08.009

5. Feng A, Wang L, Chen X, Liu X, Li L, Wang B, Luo H, Mo X, Tobe RG. Developmental Origins of Health and Disease (DOHaD): Implications for health and nutritional issues among rural children in China. Biosci Trends. 2015; 9(2):82-7. https://doi.org/10.5582/bst.2015.01008

6. Da Costa MP, Durão C, Lopes C, Vilela S. Adherence to a healthy eating index from pre-school to school age and its associations with sociodemographic and early life factors. Br J Nutr. 2019; 122(2):220-30. https://doi.org/10.1017/s0007114519001028

7. Blissett J. Relationships between parenting style, feeding style and feeding practices and fruit and vegetable consumption in early childhood. Appetite. 2011; 57(3):826-31. https://doi.org/10.1016/j.appet.2011.05.318

8. Fadare O, Amare M, Mavrotas G, Akerele D, Ogunniyi A. Mother's nutrition-related knowledge and child nutrition outcomes: Empirical evidence from Nigeria. PLoS One. 2019; 14(2):e0212775. https://doi.org/10.1371/journal.pone.0212775

9. Xu N, Zhang G, Xie G, Chen L, Han A, Su P. Dietary literacy questionnaire for school-age children's daily diet providers and its reliability and validity. Hygiene Res. 2020; 49(04):546-53. https://doi.org/10.19813/j.cnki.weishengyanjiu.2020.04.004 
10. Begley A, Butcher LM, Bobongie V, Dhaliwal SS. Identifying participants who would benefit the most from an adult food-literacy program. Int J Environ Res Public Health. 2019; 16(7). https://doi.org/10.3390/ijerph16071272

11. Wardle J, Guthrie CA, Sanderson S, Rapoport L. Development of the Children's Eating Behaviour Questionnaire. J Child Psychol Psychiatry. 2001; 42(7):963-70. https://doi.org/10.1111/1469-7610.00792

12. Zhang Y, Liu S, Li Y, Li X, Ren P, Luo F. The Relationships between weight status and physical fitness among Chinese children and youth. Res Q Exerc Sport. 2019; 90(2):113-22. https://doi.org/10.1080/02701367.2019.1603768

13. Fang HY, Zhai Y, Zhao LY, Yu DM, Zhang Q, Ju LH, Yu WT, Zhao WH. Epidemiological characteristics of overweight and obesity in Chinese children and adolescents aged 6-17 years. Chin J Epidemiol. 2018; 39(6):724-27. https://doi.org/10.3760/cma.j.issn.0254-6450.2018.06.006

14. Tao RW, Wan YH, Zhang H, Wang YF, Wang B, Xu L, Zuo AZ, Tong SL, Tao FB. Relationship between hypertension and percentage of body fat in children of Anhui province. Chin J Epidemiol. 2016; 37(2):178-82. https://doi.org/10.3760/cma.j.issn.0254-6450.2016.02.005

15. Finkelstein JL, Mehta S, Villalpando S, Mundo-Rosas V, Luna SV, Rahn M, Shamah-Levy T, Beebe SE, Haas JD. A randomized feeding trial of IronBiofortified Beans on school children in Mexico. Nutrients. 2019; 11(2). https://doi.org/10.3390/nu11020381

16. Vázquez-Velázquez V, Kaufer-Horwitz M, Méndez JP, García-García E, Reidl-Martínez LM. Eating behavior and psychological profile: Associations between daughters with distinct eating disorders and their mothers. BMC Womens Health. 2017; 17(1):74. https://doi.org/10.1186/s12905-017-0430-y

17. Lee HA, Park H. The mediation effect of individual eating behaviours on the relationship between socioeconomic status and dietary quality in children: The Korean National Health and Nutrition Examination Survey. Eur J Nutr. 2017; 56(3):1339-46. https://doi.org/10.1007/s00394-016-1184-2

18. Iglesias Vázquez L, Valera E, Villalobos M, Tous M, Arija V. Prevalence of Anemia in children from Latin America and the caribbean and effectiveness of nutritional interventions: Systematic review and meta-analysis. Nutrients. 2019; 11(1). https://doi.org/10.3390/nu11010183

19. Kang M, Kim DW, Jung HJ, Shim JE, Song Y, Kim K, Paik HY. Dietary supplement use and nutrient intake among children in South Korea. J Acad Nutr Diet. 2016; 116(8):1316-22. https://doi.org/10.1016/j.jand.2016.02.020

20. Lindsay AC, Sitthisongkram S, Greaney ML, Wallington SF, Ruengdej P. Non-responsive feeding practices, unhealthy eating behaviors, and risk of child overweight and obesity in Southeast Asia: A systematic review. Int J Environ Res Public Health. 2017; 14(4). https://doi.org/10.3390/ijerph14040436

21. Meule A, Lutz AP, Vögele C, Kübler A. Impulsive reactions to food-cues predict subsequent food craving. Eat Behav. 2014; 15(1):99-105. https://doi.org/10.1016/j.eatbeh.2013.10.023

22. Malik VS, Schulze MB, Hu FB. Intake of sugar-sweetened beverages and weight gain: A systematic review. Am J Clin Nutr. 2006; 84(2):274-88. https://doi.org/10.1093/ajcn/84.1.274

23. Ngatia EM, Ng'ang'a PM, Muita JW, Imungi JK. Dietary patterns and nutritional status of pre-school children in Nairobi. East Afr Med J. 2005; 82(10):520-5. https://doi.org/10.4314/eamj.v82i10.9350

24. Scaglioni S, De Cosmi V, Ciappolino V, Parazzini F, Brambilla P, Agostoni C. Factors Influencing children's eating behaviours. Nutrients. 2018; 10(6). https://doi.org/10.3390/nu10060706

25. Konidari Z, Kastorini CM, Milionis HJ, Bika E, Nikolaou V, Vemmos KN, Goudevenos JA, Panagiotakos DB. Eating behaviors and their relationship with cardiovascular disease. A case/case-control study. Appetite. 2014; 80:89-95. https://doi.org/10.1016/j.appet.2014.05.005

26. Vergeer L, Vanderlee L, White CM, Rynard VL, Hammond D. Vegetarianism and other eating practices among youth and young adults in major Canadian cities. Public Health Nutr. 2020; 23(4):609-19. https://doi.org/10.1017/s136898001900288x

\section{Tables}

Table 1 Comparison of daily diet providers' dietary literacy scores between different demographic characteristics 


\begin{tabular}{|c|c|c|c|c|c|c|}
\hline \multirow[t]{2}{*}{ Characteristics } & \multirow[t]{2}{*}{$\mathrm{N}(\%)$} & \multirow{2}{*}{$\begin{array}{l}\text { Attitude } \\
\text { Mean SD }\end{array}$} & \multirow{2}{*}{$\begin{array}{l}\text { Behaviour } \\
\text { Mean SD }\end{array}$} & \multirow{2}{*}{$\begin{array}{l}\text { Skill } \\
\text { Mean SD }\end{array}$} & \multirow{2}{*}{$\begin{array}{l}\text { Environment } \\
\text { Mean SD }\end{array}$} & \multirow{2}{*}{$\begin{array}{l}\text { Total score } \\
\text { Mean SD }\end{array}$} \\
\hline & & & & & & \\
\hline \multicolumn{7}{|l|}{ Region } \\
\hline Cities & $693(66.4)$ & 15.02 .7 & 15.33 .5 & 19.04 .1 & 14.02 .8 & 63.210 .3 \\
\hline Countryside & $350(33.6)$ & 13.63 .2 & 14.33 .9 & 18.14 .5 & 12.83 .2 & 58.711 .5 \\
\hline$p$ & & $<.001$ & $<.001$ & .001 & $<.001$ & $<.001$ \\
\hline \multicolumn{7}{|l|}{ Relationship with child } \\
\hline Parents & $894(85.7)$ & 14.72 .8 & 15.13 .5 & 18.94 .1 & 13.82 .8 & 62.510 .4 \\
\hline Grandparents & $128(12.3)$ & 13.23 .4 & 13.74 .1 & 17.34 .9 & 12.43 .5 & 56.612 .7 \\
\hline Other & $21(2.0)$ & 13.13 .6 & 13.84 .5 & 19.04 .6 & 12.63 .7 & 58.313 .3 \\
\hline$p$ & & $<.001$ & $<.001$ & $<.001$ & $<.001$ & $<.001$ \\
\hline \multicolumn{7}{|l|}{ Diet provider age } \\
\hline$₫ 30$ years & $44(4.2)$ & 14.43 .1 & 14.64 .1 & 19.04 .7 & 13.13 .3 & 61.012 .6 \\
\hline 30 40years & $649(62.2)$ & 14.82 .8 & 15.23 .4 & 19.04 .0 & 13.92 .8 & 62.910 .1 \\
\hline 40 50years & $223(21.4)$ & 14.33 .0 & 15.03 .7 & 18.44 .4 & 13.43 .1 & 61.111 .2 \\
\hline $50 \sim 60$ years & $47(4.5)$ & 13.53 .5 & 14.54 .6 & 18.34 .3 & 13.33 .5 & 59.512 .5 \\
\hline \$60years & $80(7.7)$ & 13.23 .2 & 13.33 .8 & 16.94 .9 & 12.03 .3 & 55.312 .1 \\
\hline$p$ & & $<.001$ & $<.001$ & $<.001$ & $<.001$ & $<.001$ \\
\hline \multicolumn{7}{|l|}{ Education } \\
\hline Primary school or lower & 197(18.9) & 13.33 .2 & 13.84 .0 & 17.84 .8 & 12.43 .1 & 57.212 .0 \\
\hline Junior middle school & $417(40.0)$ & 14.63 .0 & 15.03 .5 & 18.74 .2 & 13.92 .8 & 62.210 .4 \\
\hline High school & $233(22.3)$ & 15.02 .6 & 15.53 .8 & 19.34 .1 & 13.93 .0 & 63.611 .1 \\
\hline College and higher & 196(18.8) & 14.92 .6 & 15.33 .1 & 18.93 .7 & 13.82 .8 & 62.99 .5 \\
\hline$p$ & & $<.001$ & $<.001$ & .001 & $<.001$ & $<.001$ \\
\hline
\end{tabular}

Table 2 Comparison of partial nutritional status of children in different dietary literacy groups 


\begin{tabular}{|c|c|c|c|c|c|c|c|c|c|}
\hline \multirow[t]{2}{*}{ Dietary literacy } & \multirow[t]{2}{*}{$N(\%)$} & \multicolumn{3}{|c|}{ Body fat percentage ${ }^{a}$} & \multicolumn{3}{|l|}{$\mathrm{BMI}^{\mathrm{b}}$} & \multicolumn{2}{|c|}{ Haemoglobin ${ }^{c}$} \\
\hline & & Normal & High & Low & Normal & Wasting & $\begin{array}{l}\text { Overweight } \\
\text { or obesity }\end{array}$ & Normal & Deficiency \\
\hline \multicolumn{10}{|l|}{ Attitude } \\
\hline Low score $<13$ & $233(22.3)$ & 109 & 63 & 61 & 147 & 21 & 65 & 219 & $14(6.0)$ \\
\hline Moderate score 13-17 & $652(62.5)$ & 327 & 166 & 159 & 483 & 31 & 138 & 590 & $62(9.5)$ \\
\hline High score $>17$ & $158(15.2)$ & 79 & 35 & 44 & 103 & 14 & 41 & 142 & $16(10.1)$ \\
\hline$x^{2}$ & & 2.00 & & & 14.29 & & & 3.01 & \\
\hline$p$ & & .735 & & & .006 & & & .222 & \\
\hline \multicolumn{10}{|l|}{ Behaviour } \\
\hline Low score $<13$ & $246(23.6)$ & 116 & 66 & 64 & 178 & 12 & 56 & 226 & $20(8.1)$ \\
\hline Moderate score $13-18$ & $610(58.5)$ & 306 & 153 & 151 & 432 & 39 & 139 & 554 & $56(9.2)$ \\
\hline High score >18 & $187(17.9)$ & 93 & 45 & 49 & 123 & 15 & 49 & 171 & $16(8.6)$ \\
\hline$x^{2}$ & & 0.86 & & & 3.15 & & & 0.26 & \\
\hline$p$ & & .930 & & & .532 & & & .878 & \\
\hline \multicolumn{10}{|l|}{ Skill } \\
\hline Low score $<16$ & $222(21.3)$ & 109 & 58 & 55 & 157 & 17 & 48 & 202 & $20(9.0)$ \\
\hline Moderate score $16-22$ & $605(58.0)$ & 290 & 162 & 153 & 420 & 40 & 145 & 551 & $54(8.9)$ \\
\hline High score $>22$ & $216(20.7)$ & 116 & 44 & 56 & 156 & 9 & 51 & 198 & 18(8.3) \\
\hline$\chi^{2}$ & & 3.79 & & & 2.87 & & & 0.08 & \\
\hline$p$ & & .435 & & & .581 & & & .960 & \\
\hline \multicolumn{10}{|l|}{ Environment } \\
\hline Low score $<12$ & $251(24.1)$ & 121 & 65 & 65 & 183 & 16 & 52 & 228 & $23(9.2)$ \\
\hline Moderate score $12-16$ & $614(58.9)$ & 294 & 160 & 160 & 429 & 39 & 146 & 557 & $57(9.3)$ \\
\hline High score $>16$ & $178(17.0)$ & 100 & 39 & 39 & 121 & 11 & 46 & 166 & $12(6.7)$ \\
\hline$\chi^{2}$ & & 3.98 & & & 1.67 & & & 1.16 & \\
\hline$p$ & & .409 & & & .797 & & & .561 & \\
\hline \multicolumn{10}{|l|}{ Total score } \\
\hline Low score $<55$ & $258(24.7)$ & 125 & 66 & 67 & 183 & 16 & 59 & 236 & $22(8.5)$ \\
\hline Moderate score $55-70$ & $550(52.7)$ & 261 & 153 & 136 & 393 & 39 & 118 & 500 & $50(9.1)$ \\
\hline High score $>70$ & $235(22.6)$ & 129 & 45 & 61 & 157 & 11 & 67 & 215 & $20(8.5)$ \\
\hline$\chi^{2}$ & & 6.96 & & & 5.59 & & & 0.11 & \\
\hline$p$ & & .138 & & & .232 & & & .949 & \\
\hline
\end{tabular}

${ }^{\text {a }} P_{25}-P_{75}$ was used as normal group, $<P_{25}$ as low body fat group, $>P_{75}$ as high body fat group; ${ }^{b}$ Detailed BMI classification was shown in Supplemental Table 2; $9 \mathrm{HB}<115 \mathrm{~g} / \mathrm{L}$ in children aged 5 to 11 and $\mathrm{Hb}<120 \mathrm{~g} / \mathrm{L}$ in children older than 11 were considered as deficiency.

Table 3 Comparison of trace elements status among children in different dietary literacy groups 


\begin{tabular}{|c|c|c|c|c|c|c|c|}
\hline \multirow[t]{2}{*}{ Dietary literacy } & \multirow[t]{2}{*}{$\mathrm{N}(\%)$} & \multicolumn{2}{|l|}{ Calcium } & \multicolumn{2}{|l|}{ Iron } & \multicolumn{2}{|l|}{ Zinc } \\
\hline & & Normal & Deficiency & Normal & Deficiency & Normal & Deficiency \\
\hline \multicolumn{8}{|l|}{ Attitude } \\
\hline Low score & 233(22.3) & 192 & 41 & 189 & 44 & 213 & 20 \\
\hline Moderate score & $652(62.5)$ & 494 & 158 & 533 & 119 & 565 & 87 \\
\hline High score & 158(15.2) & 126 & 32 & 131 & 27 & 141 & 17 \\
\hline$x^{2}$ & & 4.77 & & 0.20 & & 3.94 & \\
\hline$p$ & & .092 & & .903 & & .140 & \\
\hline \multicolumn{8}{|l|}{ Behaviour } \\
\hline Low score & $246(23.6)$ & 191 & 55 & 203 & 43 & 213 & 33 \\
\hline Moderate score & $610(58.5)$ & 480 & 130 & 497 & 113 & 537 & 73 \\
\hline High score & 187(17.9) & 141 & 46 & 153 & 34 & 169 & 18 \\
\hline$x^{2}$ & & 0.91 & & 0.13 & & 1.47 & \\
\hline$p$ & & .636 & & .938 & & .481 & \\
\hline \multicolumn{8}{|l|}{ Skill } \\
\hline Low score & $222(21.3)$ & 178 & 44 & 177 & 45 & 185 & 37 \\
\hline Moderate score & $605(58.0)$ & 469 & 136 & 498 & 107 & 541 & 64 \\
\hline High score & 216(20.7) & 165 & 51 & 178 & 38 & 193 & 23 \\
\hline$x^{2}$ & & 1.01 & & 0.80 & & 6.15 & \\
\hline$p$ & & .605 & & .671 & & .146 & \\
\hline \multicolumn{8}{|l|}{ Environment } \\
\hline Low score & $251(24.0)$ & 198 & 53 & 211 & 40 & 224 & 27 \\
\hline Moderate score & $614(58.9)$ & 474 & 140 & 500 & 114 & 540 & 74 \\
\hline High score & 178(17.1) & 140 & 38 & 142 & 36 & 155 & 23 \\
\hline$x^{2}$ & & 0.37 & & 1.41 & & 0.50 & \\
\hline$p$ & & .830 & & .495 & & .777 & \\
\hline \multicolumn{8}{|l|}{ Total score } \\
\hline Low score & $258(24.7)$ & 206 & 52 & 212 & 46 & 228 & 30 \\
\hline Moderate score & $550(52.7)$ & 429 & 121 & 451 & 99 & 479 & 71 \\
\hline High score & $235(22.6)$ & 177 & 58 & 190 & 45 & 212 & 23 \\
\hline$x^{2}$ & & 1.48 & & 0.18 & & 1.55 & \\
\hline$p$ & & .478 & & .914 & & .460 & \\
\hline
\end{tabular}

The cut-offs of dietary literacy are the same as Table 2; Reference ranges of normal values of $\mathrm{Ca}$, Fe, and $\mathrm{Zn}$ in children aged 6 to 11 years were 1.51 to 2.01 $\mathrm{mmol} / \mathrm{L}, 7.36$ to $9.34 \mathrm{mmol} / \mathrm{L}$, and 67.72 to $103.84 \mu \mathrm{mol} / \mathrm{L}$, respectively; Reference ranges of normal values of $\mathrm{Ca}$, Fe, and $\mathrm{Zn}$ in children aged 12 to 14 years were 1.42 to $1.90 \mathrm{mmol} / \mathrm{L}, 7.16$ to $9.85 \mathrm{mmol} / \mathrm{L}$, and 71.46 to $111.33 \mu \mathrm{mol} / \mathrm{L}$, respectively.

Table 4 Comparison of eating behavior of children in different dietary literacy of daily diet providers 


\begin{tabular}{|c|c|c|c|c|c|c|c|c|}
\hline \multirow[t]{2}{*}{$\begin{array}{l}\text { Dietary } \\
\text { literacy }\end{array}$} & $\begin{array}{l}\text { Satiety } \\
\text { responsiveness }\end{array}$ & $\begin{array}{l}\text { Slowness in } \\
\text { eating }\end{array}$ & $\begin{array}{l}\text { Food } \\
\text { fussiness }\end{array}$ & $\begin{array}{l}\text { Food } \\
\text { responsiveness }\end{array}$ & $\begin{array}{l}\text { Enjoyment of } \\
\text { food }\end{array}$ & $\begin{array}{l}\text { Desire to } \\
\text { drink }\end{array}$ & $\begin{array}{l}\text { Emotional } \\
\text { undereating }\end{array}$ & $\begin{array}{l}\text { Emotional } \\
\text { overeating }\end{array}$ \\
\hline & Mean SD & Mean SD & Mean SD & Mean SD & Mean SD & Mean SD & Mean SD & Mean SD \\
\hline \multicolumn{9}{|l|}{ Attitude } \\
\hline Low score & 12.73 .7 & 10.33 .5 & 16.14 .1 & 11.44 .2 & 13.13 .8 & 6.63 .0 & $10.3 \quad 3.3$ & 8.23 .5 \\
\hline $\begin{array}{l}\text { Moderate } \\
\text { score }\end{array}$ & 12.43 .3 & 10.03 .2 & 15.24 .1 & 10.43 .9 & 13.83 .7 & 6.12 .9 & 10.03 .1 & 7.23 .0 \\
\hline High score & 11.92 .9 & 9.63 .2 & 14.24 .2 & 10.14 .0 & 14.54 .1 & 5.92 .8 & 9.83 .4 & 6.32 .9 \\
\hline$F$ & 3.17 & 1.79 & 9.74 & 6.77 & 6.64 & 2.91 & 1.06 & 18.6 \\
\hline$p$ & .042 & .167 & $<.001$ & .001 & .001 & .055 & .347 & $<.001$ \\
\hline \multicolumn{9}{|l|}{ Behaviour } \\
\hline Low score & 12.83 .5 & 10.13 .3 & 15.94 .1 & 11.14 .0 & 13.23 .7 & 6.73 .1 & $10.3 \quad 3.3$ & 7.93 .2 \\
\hline $\begin{array}{l}\text { Moderate } \\
\text { score }\end{array}$ & 12.43 .2 & 10.13 .3 & 15.34 .0 & 10.64 .0 & 13.83 .6 & 6.12 .8 & 10.03 .1 & 7.23 .1 \\
\hline High score & 11.93 .5 & 9.83 .3 & 14.34 .6 & 9.73 .6 & 14.24 .3 & 5.83 .0 & 9.73 .4 & 6.73 .1 \\
\hline$F$ & 3.85 & 0.77 & 7.82 & 7.11 & 3.80 & 5.74 & 1.84 & 7.84 \\
\hline$p$ & .022 & .466 & $<.001$ & .001 & .023 & .003 & .159 & $<.001$ \\
\hline \multicolumn{9}{|l|}{ Skill } \\
\hline Low score & 12.93 .3 & 10.53 .5 & 16.74 .3 & 11.14 .0 & 13.43 .5 & 7.03 .2 & 10.13 .4 & 7.53 .4 \\
\hline $\begin{array}{l}\text { Moderate } \\
\text { score }\end{array}$ & 12.63 .3 & 10.03 .3 & 15.23 .8 & 10.73 .9 & 13.63 .6 & 6.12 .7 & 10.13 .1 & $7.3 \quad 3.1$ \\
\hline High score & 12.03 .4 & 9.73 .0 & 14.04 .4 & 9.74 .0 & 14.54 .3 & 5.63 .0 & 9.73 .4 & 7.03 .2 \\
\hline$F$ & 3.74 & 4.23 & 25.47 & 7.28 & 5.56 & 12.72 & 1.26 & 1.94 \\
\hline$p$ & .024 & .015 & $<.001$ & .001 & .004 & $<.001$ & .283 & .144 \\
\hline \multicolumn{9}{|c|}{ Environment } \\
\hline Low score & 13.03 .6 & 10.33 .3 & 16.04 .0 & 11.24 .2 & 13.03 .8 & 6.52 .9 & 10.23 .2 & 7.93 .4 \\
\hline $\begin{array}{l}\text { Moderate } \\
\text { score }\end{array}$ & 12.43 .3 & 10.03 .4 & 15.24 .2 & 10.63 .9 & 13.93 .7 & 6.33 .0 & 10.13 .2 & 7.23 .0 \\
\hline High score & 11.63 .0 & 9.93 .0 & 14.64 .2 & 9.53 .8 & 14.14 .0 & 5.32 .6 & $9.3 \quad 3.3$ & 6.63 .2 \\
\hline$F$ & 8.81 & 0.87 & 5.95 & 10.22 & 6.92 & 10.90 & 5.88 & 9.44 \\
\hline$p$ & $<.001$ & .419 & .003 & $<.001$ & .001 & $<.001$ & .003 & $<.001$ \\
\hline \multicolumn{9}{|l|}{ Total score } \\
\hline Low score & 12.93 .6 & 10.33 .3 & 16.24 .1 & 11.64 .0 & 13.23 .5 & 6.63 .0 & 10.43 .4 & 8.13 .4 \\
\hline $\begin{array}{l}\text { Moderate } \\
\text { score }\end{array}$ & 12.43 .3 & 10.03 .3 & 15.34 .0 & 10.64 .0 & 13.73 .7 & 6.22 .8 & 10.03 .8 & 7.23 .0 \\
\hline High score & 11.83 .1 & 9.83 .2 & 14.24 .5 & 9.43 .6 & 14.44 .2 & 5.63 .0 & 9.63 .4 & 6.63 .0 \\
\hline$F$ & 6.96 & 1.30 & 14.05 & 18.73 & 6.12 & 6.99 & 3.35 & 14.85 \\
\hline$p$ & .001 & .274 & $<.001$ & $<.001$ & .002 & .001 & .036 & $<.001$ \\
\hline
\end{tabular}

The cut-offs of dietary literacy are the same as Table 2; The df of analysis of variance between groups and within groups are 2 and 1040, respectively.

Table 5 Effect of daily diet providers' dietary literacy score on children's eating behaviours 


\begin{tabular}{|c|c|c|c|c|c|c|c|c|c|c|c|c|c|c|c|c|}
\hline \multirow[t]{2}{*}{$\begin{array}{l}\text { Dietary } \\
\text { literacy }\end{array}$} & \multicolumn{3}{|c|}{$\begin{array}{l}\text { Satiety } \\
\text { responsiveness }\end{array}$} & \multicolumn{3}{|c|}{ Slowness in eating } & \multicolumn{3}{|c|}{ Food fussiness } & \multicolumn{3}{|c|}{ Food responsiveness } & $\begin{array}{l}\text { Enjoyment } \\
\text { of food }\end{array}$ & $\begin{array}{l}\text { Desire } \\
\text { to } \\
\text { drink }\end{array}$ & $\begin{array}{l}\text { Emotional } \\
\text { undereating }\end{array}$ & \multirow{2}{*}{$\begin{array}{l}E \\
\text { ' } \\
\beta\end{array}$} \\
\hline & $\beta$ & $t$ & $p$ & $\boldsymbol{\beta}$ & $t$ & $p$ & $\beta$ & $t$ & $p$ & $\beta$ & $t$ & $p$ & $\begin{array}{lll}\beta & t & p\end{array}$ & ${ }_{p}^{\beta} t$ & $\beta \quad t \quad p$ & \\
\hline \multicolumn{17}{|l|}{ Attitude } \\
\hline \multirow[t]{2}{*}{$\begin{array}{l}\text { Moderate } \\
\text { score }\end{array}$} & -0.02 & -0.62 & .535 & -0.06 & -1.53 & .126 & -0.09 & -2.28 & .023 & -0.10 & -2.58 & .010 & $\begin{array}{l}0.082 .05 \\
.040\end{array}$ & $\begin{array}{l}-0.09 \\
-2.44\end{array}$ & $\begin{array}{c}-0.04-0.95 \\
.342\end{array}$ & -0 \\
\hline & & & & & & & & & & & & & & .015 & & \\
\hline \multirow[t]{2}{*}{ High score } & -0.07 & -1.93 & .053 & -0.10 & -2.60 & .010 & -0.15 & -4.15 & $<.001$ & -0.09 & -2.54 & .011 & $\begin{array}{l}0.123 .18 \\
.002\end{array}$ & $\begin{array}{l}-0.10 \\
-2.80\end{array}$ & $\begin{array}{l}-0.04-1.10 \\
.271\end{array}$ & -0 \\
\hline & & & & & & & & & & & & & & .005 & & \\
\hline \multicolumn{17}{|l|}{ Behaviour } \\
\hline \multirow[t]{2}{*}{$\begin{array}{l}\text { Moderate } \\
\text { score }\end{array}$} & -0.04 & -0.97 & .334 & -0.01 & -0.05 & .958 & -0.06 & -1.60 & .109 & -0.04 & -1.02 & .310 & $\begin{array}{c}0.071 .79 \\
.074\end{array}$ & $\begin{array}{l}-0.12 \\
-3.28\end{array}$ & $\begin{array}{l}-0.05-1.30 \\
.194\end{array}$ & $\begin{array}{l}-0 \\
-4\end{array}$ \\
\hline & & & & & & & & & & & & & & .001 & & \\
\hline High score & -0.08 & -2.103 & .036 & -0.05 & -1.22 & .223 & -0.14 & -3.79 & $\stackrel{<}{<001}$ & -0.12 & -3.12 & .002 & $\begin{array}{l}0.082 .11 \\
.035\end{array}$ & $\begin{array}{c}-0.14 \\
-3.69 \\
< \\
.001\end{array}$ & $\begin{array}{c}-0.07-1.76 \\
.080\end{array}$ & $\begin{array}{l}-0 \\
-i \\
.\end{array}$ \\
\hline \multicolumn{17}{|l|}{ Skill } \\
\hline $\begin{array}{l}\text { Moderate } \\
\text { score }\end{array}$ & -0.07 & -1.74 & .082 & -0.10 & -2.70 & .007 & -0.19 & -4.92 & $<.001$ & -0.03 & -0.71 & .478 & $\begin{array}{l}0.020 .58 \\
.561\end{array}$ & $\begin{array}{c}-0.16 \\
-4.05 \\
< \\
.001\end{array}$ & $\begin{array}{c}-0.01-0.12 \\
.907\end{array}$ & $\begin{array}{l}-0 \\
-1 \\
.\end{array}$ \\
\hline High score & -0.09 & -2.28 & .023 & -0.12 & -3.02 & .003 & -0.27 & -7.02 & $\stackrel{<}{.001}$ & -0.13 & -3.24 & .001 & $\begin{array}{l}0.102 .66 \\
.008\end{array}$ & $\begin{array}{c}-0.20 \\
-5.13 \\
< \\
.001\end{array}$ & $\begin{array}{l}-0.05-1.39 \\
.164\end{array}$ & $\begin{array}{l}-0 \\
-1 \\
.1\end{array}$ \\
\hline \multicolumn{17}{|c|}{ Environment } \\
\hline \multirow[t]{2}{*}{$\begin{array}{l}\text { Moderate } \\
\text { score }\end{array}$} & -0.07 & -1.79 & .074 & -0.03 & -0.89 & .375 & -0.10 & -2.65 & .008 & -0.07 & -1.86 & .064 & $\begin{array}{l}0.112 .87 \\
\quad .004\end{array}$ & $\begin{array}{l}-0.04 \\
-1.16\end{array}$ & $\begin{array}{c}-0.01-0.29 \\
.771\end{array}$ & -0 \\
\hline & & & & & & & & & & & & & & .249 & & \\
\hline High score & -0.13 & -3.54 & $<.001$ & -0.06 & -1.67 & .095 & -0.12 & -3.16 & .002 & -0.15 & -3.98 & $<.001$ & $\begin{array}{l}0.092 .54 \\
.011\end{array}$ & $\begin{array}{c}-0.18 \\
-4.84 \\
< \\
.001\end{array}$ & $\begin{array}{c}-0.11-2.83 \\
.005\end{array}$ & $\begin{array}{l}-0 \\
-\vdots \\
.0\end{array}$ \\
\hline \multicolumn{17}{|l|}{ Total score } \\
\hline \multirow[t]{2}{*}{$\begin{array}{l}\text { Moderate } \\
\text { score }\end{array}$} & -0.06 & -1.57 & .116 & -0.05 & -1.36 & .175 & -0.11 & -2.89 & .004 & -0.10 & -2.75 & .006 & $\begin{array}{l}0.051 .42 \\
.157\end{array}$ & $\begin{array}{l}-0.09 \\
-2.46\end{array}$ & $\begin{array}{c}-0.05-1.38 \\
.167\end{array}$ & $\begin{array}{l}-0 \\
-\vdots\end{array}$ \\
\hline & & & & & & & & & & & & & & .014 & & \\
\hline High score & -0.11 & -2.82 & .005 & -0.08 & -2.16 & .031 & -0.19 & -5.09 & $<.001$ & -0.20 & -5.39 & $<.001$ & $\begin{array}{l}0.112 .77 \\
.006\end{array}$ & $\begin{array}{c}-0.17 \\
-4.43 \\
< \\
.001\end{array}$ & $\begin{array}{c}-0.09-2.44 \\
.015\end{array}$ & $\begin{array}{l}-0 \\
-4 \\
.0\end{array}$ \\
\hline
\end{tabular}

The groups of dietary literacy are the same as Table 2 and the low score group was taken as the reference group.

\section{Supplementary Files}

This is a list of supplementary files associated with this preprint. Click to download.

- Additionalfile1.docx

- Additionalfile2.docx

- Informedconsent.docx 